\title{
STEFAN JONSSON
}

Professor vid Institutet för forskning om migration, etniska

relationer och samhälle, REMESO, Linköpings universitet

\section{TOTAL TEATER SAMHÄLLSUTOPIER PÅ SCEN UNDER WEIMARREPUBLIKEN}

\author{
TOTAL THEATRE • STAGING UTOPIA IN THE WEIMAR REPUBLIC | Highlight- \\ ing a crucial topic in the utopian aesthetics developed in the European interwar period, this article \\ discusses the radical ideas of placing society on stage, and of turning theatre into a medium for the \\ self-representation of society. Illustrations and examples are drawn mainly from Erwin Piscator, and \\ his collaboration with Walter Gropius in a project that they conceived of as "the Total Theatre" (Das \\ Totaltheater). As the essay argues, these ideas of a new stage craft and performance were perhaps the \\ most daring interventions among the wild and unruly democratic experiments of the Weimar Repub- \\ lic, and they usefully illustrate what Walter Benjamin had in mind as he, in the same period, crypti- \\ cally endorsed the aesthetico-political idea of an artwork that is "being absorbed by the masses". \\ KEYWORDS I theatre and drama, Germany, Weimar Re- \\ public, social movements, masses, Erwin Piscator.
}

Alla konstnärliga och litterära yttringar i Tysklands Weimarrepublik överskred gränsen mellan estetik och politik, och ingenstans var gränsöverskridandet tydligare än inom scenkonsten. Mitt i de sociala och politiska kriser som följde på första världskriget stod en yngre generation dramatiker och regissörer som förkastade vad de såg på europeiska teaterscener. Domen föll särskilt hårt mot det psykologiskt orienterade naturalistiska dramat med den borgerliga individen i hjälterollen. Dessa dramatiker och regissörer önskade sig en ny teater som förmådde gripa in i samtidens brännande problem, från hungern till extremhögerns våld, från den kapitalistiska utsugningen till kvinnans rättigheter. Med denna nya teater som utgångspunkt önskade de förändra världen. När de sökte dramatiska former som kunde uppfylla de utopiska önskningarna blickade de tillbaka på den situation som de föreställde sig hade rått i det antika Grekland, där teatern var samhällets kulturella centrum, ett estetiskt prisma som sammanförde gemenskapens konflikter och bekymmer till en brännpunkt. Som dessa Weimarintellektuella såg saken, skulle teatern inte vara skild från samhället utan göras till en politisk och kulturell arena där samhället blev gestaltat, granskat och representerat, och i så måtto var teatern lika viktig som parlamentet och pressen (Piscator, Politische Theater 45). Avsikten 
med denna essä är att undersöka de utopiska energier som frigjordes när politiska och estetiska målsättningar sammanföll i mellankrigstidens tyska teaterdebatt och särskilt i Erwin Piscators program för vad han kallade Totalteatern.

\section{Vad är problemet?}

I en återblickande text från 1949 drar sig Béla Balázs till minnes det tidiga 1930-talets radikala teater. Scen: Friedrichsstraße. Skådespelare: en handfull anonyma aktörer från teatergruppen "Die Ketzer" (Kättarna) som blandat sig med fotgängarna. Pjäs: en ung man stående framför en finare livsmedelsaffär svimmar plötsligt och segnar ner på marken; en annan man rusar till undsättning, faller på knä och börjar knäppa upp den avsvimmades smutsiga skjorta för att underlätta hans andning.

Mer än så var det inte, vad som sedan följde var improvisation, skriver Balázs ("Theater auf der Straße" 455). När andra fotgängare närmade sig uppstod snart en folkhop omkring den skenbart avsvimmade mannen och formade en halvcirkel på trottoaren mot bakgrund av livsmedelsbutikens skyltfönster, där korvar, ostar, exotiska frukter och burkar med kaviar låg travade. "Vad har hänt med honom? Vad är problemet?" frågade någon. "Ni vet mycket väl vad som är problemet", svarade mannen som först rusat till och stod på knä. "Hungern! Det är det som är problemet. Kan ni inte räkna ut det själva?”

Det var den enklaste form av teater man kan tänka sig, skriver Balázs. Men under det tidiga 1930-talets depression stod gatuteater av detta slag i samklang med vardagslivet. Efter det simulerade svimningsanfallet fortsatte teatern på Friedrichsstraße av egen kraft, när församlingen av betraktare och fotgängare började diskutera arbetslösheten, de sociala orättvisorna, den ekonomiska depressionen, undernäringen, levnadsomkostnaderna och matpriserna, samtidigt som de kastade avundsjuka och hatiska blickar mot de välklädda kunderna som besökte delikatessaffären. "Javisst", skrek en man. "Dag efter dag den där sugande hungern. Jag saknar också arbete." Om stämningen i församlingen blev upprörd hände det att polisen anlände för att skingra folkmassan och förhöra de församlade, men vid det laget var skådespelarna redan på väg till ett annat gathörn, till en annan av de tillfälliga scener de valt ut för att agitera för social rättvisa (Balázs, "Theater auf der Straße" 455).

Gatuteater var vanligt förekommande under denna period därför att de lokala och regionala myndigheterna utfärdade förordningar och förbud för att förhindra kulturella och politiska evenemang som ansågs störa allmän ordning och sedlighet, något som agitprop-grupperna svarade på genom att lämna sina fasta scener och teaterlokaler för att i stället göra oannonserade aktioner i det fria (Se Pieck 271-276; Hoffmann 38-46). Själva teaterformen var inte ny. Tillfälliga teaterföreställningar på gator och torg är ett med teaterkonstens uppkomst på antikens Dionysosfestivaler och de religiösa spelen under medeltiden, där 
befolkningen $i$ en stad eller by iscensatte den egna gemenskapens uppkomst och historia i nya variationer. Socialistiska teatergrupper förnyade denna genre under den tyska revolutionen I9I8-I9I9, starkt inspirerade av den nya kulturpolitik som lanserats av Sovjetunionens kommunistiska parti. Gemensamma inspirationskällor för såväl de sovjetiska som de tyska teaterarbetarna var den unge Richard Wagners Die Kunst und die Revolution (I849) och Romain Rollands Théatre du peuple (1903), som båda förespråkade en revolutionär teater i vilken hela folket skulle kunna identifiera sina sammanhållande krafter och fira sin enhet (Kleberg). Eldade av en radikaldemokratisk kultursyn bildade journalister och kulturarbetare resande sällskap som skulle agitera och propagera - därav sammanställningen agitprop - och detta skedde ofta genom att iscensätta politiska händelser ur det nära förflutna, till exempel olika händelser under revolutionen, för att utbilda och mobilisera "massorna". I slutet av I920-talet hade snart sagt varje stad i Tyskland sin egen agitprop-teatergrupp, vilka var sammanslutna i föreningen Arbeiter-Theater-Bund Deutschlands, som i sin tur var löst knuten till Tysklands kommunistparti och som då för tiden utgjorde den största teaterorganisationen i Europa, om man bortser från Sovjetunionen. Béla Balázs arbetade i några år som konstnärlig ledare vid föreningen rikskontor. Han var också ledare för Die Ketzer (Balázs, "Theater auf der Straße" 453-454). Hur sådana föreställningar gestaltade sig får man en uppfattning om i Slatán Dudows och Bertolt Brechts film Kuble Wampe, oder Wem gehört die Welt? (Kuhle Wampe, eller Vems är världen?) från 1932. Dokumentära tagningar från ett ungkommunistiskt läger utanför Berlin visar idrottstävlingar, politiska sånger och tal, utdelningen av flygblad och politiska pamfletter, samt även ett agitprop-sällskap som kallar sig "Det röda språkröret" (Das rote Sprachrobr) och som i röda dräkter framträder på en arenateater med "Den röda enhetsfrontens sång". Filmen kombinerar ihop alla dessa inslag till ett modernistiskt montage som erbjuder åskådaren en rundtur genom det unga, proletära kollektivets vardag och utopier (Dudow, Brecht 6o).

\section{Från antikonst till politisk teater}

Vårt mål var inte att sprida konst och kultur till folket, utan att agitera och utbilda, skrev Erwin Piscator om målsättningen för den av honom 1920 grundade Proletära teatern: "inte en teater för proletariatet, utan proletär teater" (Piscator, Politische Theater 36). Även om Piscators "Proletarisches Theater" var kortlivad så förblev dess firade föreställningar och regissörens följande uppsättningar riktmärken för alla mellankrigstidens försök att använda scenen som politisk arena. Piscators teater drev fram en rad försök att reflektera över och förvandla relationen mellan estetik och politik, i vilka flera av Weimarrepublikens främsta författare och konstnärer deltog, till exempel Béla Balász, Georg Grosz, Ernst Toller, John Heartfield, och László Moholy-Nagy. Några av dem hade varit aktiva inom dadaismen, som omedelbart efter krigsslutet proklamerade konstens död. För dadaismen var det endast ett slags konst som var tänkbar efter kriget, nämligen en konst som satsade 
på att förstöra konsten som institution, vilken de beskrev som ett fält bestående av döda monument, ihåliga värden, tomma idealistiska doktriner och livsfarliga vanföreställningar.

Om många av dessa intellektuella snart övergav Dada, så berodde det inte på att de hade funnit nya estetiska och konstnärliga vägar, utan på att de ville ställa konsten i politikens tjänst. Piscators val var otvetydigt: "Vad ledningen för den proletära teatern ska sträva efter", förklarade han, är "enkelhet i uttryck och komposition, en klar och tydlig påverkan på publiken av arbetare, en underordning av alla konstnärliga medel under det revolutionära målet: medveten betoning på och agitation för klasskampens idé" (Piscator, "Über Grundlagen" 69). Enligt Piscator kunde teatern förverkliga denna målsättning genom att undersöka vad han kalllade den historiska sanningen, det vill säga sanningen sådan den utvecklades av den marxistiska teorin. "Genom anblicken av hur alla problem bearbetas, ställs i sitt större sammanhang och förevisas i sina yttersta konsekvenser, så inser massorna hur oundvikligt det öde är som beskrivs och hur det bara finns ett sätt att besegra det." (Piscator, "Bühne" 20) I ett annat sammanhang förklarade Piscator att teatern i sina mest blomstrande perioder alltid varit djupt förbunden med folkets utopiska gemenskap; och om den skulle fortsätta att ha en betydelse även under I900-talet måste den återknyta till dessa uråldriga utopiska energier. (Piscator, "Grundsätzliches" 7)

Ett sådant program innebar stora praktiska utmaningar. Hur använda teatern för att förmedla en sann bild av det kapitalistiska samhället? Hur få de arbetande klasserna att famna denna sanning? Hur förmå de arbetande klasserna att över huvud taget komma till teatern? Den som ville förverkliga sådana ambitioner måste ha en metod som kunde förvandla de arbetande klasserna både till teaterns huvudsakliga publik och till dess huvudsakliga aktör och skådespelare. Piscators ambitioner var verkligen just så väldiga. ”Teatern önskar sig folket och måste bege sig till folket, och ingen kan förbjuda teatern att göra de experiment som fordras för att upptäcka vilken väg som leder till folket" (Piscator, "Technik" 76).

Inom agitprop-rörelsen och gatuteatern hade man löst denna uppgift genom att lämna den fasta scenen för att i stället spela på fält och gator, i parker, Folkets hus och andra samlingslokaler. Folket skulle inte längre komma till teatern, utan teatern skulle komma till folket. Detta förblev ett ofta praktiserat alternativ under hela mellankrigstiden. Det hade dock sina begränsningar. Skådespelarna fick nöja sig med de allra enklaste medel - små scener, få repetitioner, liten rekvisita och knappa resurser. Piscator övergav snart denna teaterform för att pröva andra sätt att utvidga teaterns scen till sociala och politiska områden som tidigare inte hade haft någon plats inom teaterkonsten. Resultatet var en revolutionerande scenkonst, liksom en rad nya funktioner och uppgifter för dramatiker, skådespelare, regissör och andra teateryrken, och inte minst för publiken som sådan. I sin allra djärvaste form kom Piscators utopiska teateridé till uttryck i ett samarbete med arkitekten Walter Gropius, som resulterade i en gemensam vision för vad de kallade "Den Totala teatern" (Das Totaltheater). Detta var på en och samma gång en byggnad 
och ett koncept, föreställningen om ett teaterhus och en teaterkonst som kunde ta emot en masspublik på flera tusen människor och som tog teknikens och massmediernas senaste landvinningar i anspråk. Det som skulle iscensättas på denna teater var, idealt sett, samhället som sådant.

\section{Proletariatet och teknologin}

Piscators estetik vilade på två grundvalar. Den första är redan nämnd: han önskade återupprätta teaterns förbindelse till samhällslivet, folket och proletariatet - eller med andra ord till det subjekt som i Weimarkulturen kallades "massorna". Den andra grundvalen bestod av tekniken. Dit kan vi räkna filmens rörliga bilder likaväl som löpande band och scenhissar, alltsammans sådant som Piscator använde sig av för att skapa en ny multimedial upplevelse. Hans teateridé baserade sig således på just de bägge fenomen - massorna och medietekniken - som Walter Benjamin några år senare skulle identifiera som bestämmande faktorer för konstverket i den tekniska reproducerbarhetens tid (Benjamin, "Kunstwerk" 504). Genom att införliva tekniken med konsten önskade Piscator befria teknologin från dess rent instrumentella karaktär och på så vis underminera ett par förhärskande föreställningar: dels idén om tekniken som identisk med framsteget, dels idén om teatern som oberoende av det omgivande samhället. I detta försök att tillsluta eller överbrygga gapet mellan estetik och samhälle framstår Piscator som en av de främsta företrädarna av vad Peter Bürger har kallat "det historiska avantgardet”. (Bürger)

Massornas betydelse för Piscators politiska teater var flerfaldig. För det första utgjorde de den publik som teatern riktade sig till och önskade påverka, och i vars intresse den skulle verka. I en inflytelserik artikel från I9I9 hade Béla Balázs tecknat principerna för en marxistisk dramaturgi som betonade teaterns möjlighet att främja publikens klassmedvetande. I Balász' argument fanns tydliga spår av dåtidens tongivande masspsykologiska paradigm. Han värdesatte teatern som en kollektiv erfarenhet som förmådde framställa inget mindre än en "massornas själ, en massa som inte är formad av isolerade atomer eller anhopade individer, utan en massa som i sin dionysiska hängivenhet verkligen uppnår ett enat medvetande". Balász betonade att "massan är scenkonstverkens själ och mening" (Balász, "Theater des Volkes” 2OI).

Men även om teatern ägde en hypnotisk potential, måste den undvika att manipulera massan, och den fick inte spela enbart på känslorna. I sina produktioner balanserade Piscator det affektiva uttrycket mot den intellektuella koncentrationen. Entusiasm eller kontemplation, känslomässiga utbrott eller rationell förståelse: den politiska teatern måste vara en syntes av båda, men alltid kalibrerad så att publikens lidelser riktas mot rationell och meningsfull politisk handling. Mot Sergej Eisensteins hävdande att filmkonstens avsikt var att elektrifiera massorna invände Piscator att i så fall skulle man ju lika gärna kunna ersätta filmen med boxningsmatcher och hästkapplöpningar - "vår avsikt är inte bara att entusiasmera, 
vi önskar förmedla klarhet och igenkännande” (Innes 30). Ett exempel på Piscators förmåga att kombinera exemplarisk socialistisk pedagogik med elektrifierande underhållning var hans Revue Rote Rummel (I924). Alla den billiga underhållningens beståndsdelar ingick, och mycket annat därtill. Formen var lånad från populära varietéföreställningar. Föreställningen bestod av fjorton åtskilda episoder, eller "bilder", med inslag av musik, sång, diabilder, aktionsmåleri, boxning, akrobatik, film, dans, slagord och statistik. Den förhäxande blandningen strukturerades kring ett gemensamt tema och ramades in av en löpande kommentar framförd av två skådespelare vilka personifierade borgerligheten respektive proletariatet. På så vis kom den iscensatta varietén av händelser, sketcher, sånger och cirkusnummer till användning för att diskutera den pågående utsugningen av Tysklands arbetande klasser (Piscator, Politische Theater 6I; Innes 43-47).

Piscators målsättning var att förvandla teaterpubliken till ett tänkande och diskuterande kollektiv. Därför ifrågasatte han individualitetens betydelse. Detta gällde skådespelarna, som inte förväntades inscenera individuella karaktärer utan i stället gestalta kollektiva rörelser, samhällsklasser eller historiska tendenser. Det gällde även dramatikern eller pjäsförfattaren, som knappast hade till uppgift att författa ett färdigt teaterstycke med detaljerade scenanvisningar, och inte heller hade någon auktoritet i pjästolkningen; författaren skulle snarare leverera ett arbetsmaterial som kunde bearbetas av regissören i samarbete med den övriga teatergruppen. Sist och slutligen gällde den anti-individualistiska hållningen själva publiken, som inte tilltalades eller appellerades som ett antal avskilda personer utan som delar av en massa eller ett kollektiv, där alla var delaktiga i en och samma teatererfarenhet och gärna också tilläts påverka föreställningen.

Piscators verkliga bedrift, och skälet till hans bestående ryktbarhet, var dock hans förmåga att uppfinna en rad nya tekniker som tillät honom att göra en scenisk representation av vad man kan kalla kapitalismens kronotop. Målet var att undervisa publiken om hur världen var ordnad, att hjälpa åskådarna att förstå sin gemensamma belägenhet, samt uppmana dem till samordnad handling. För att uppnå detta ansträngde sig Piscator att i teaterns rum införa inte bara en föreställning om de olika samhällsklasserna, utan också en idé om de världsomfattande sammanhang som bestämde deras positioner. Dramatikens intrig förvandlades gärna till en konflikt mellan överindividuella krafter. Föreställningen satsade på att ge gestalt och konkretion åt abstrakta fenomen som klasskampen, inflationen, de ekonomiska cyklerna, mervärdet, rättsväsendet och det imperialistiska kriget - allt för att visa hur sådana fenomen låg bakom såväl samhällets stora motsättningar som vardagens levnadsförhållanden och konflikter. Med sådana avsikter utvidgade Piscator teaterkonstens verktygslåda, så att dess specialeffekter också kom att omfatta avancerad mekanisk teknik och massmedia. Skådespelarnas agerande och dialog skars ner och kombinerades ihop med de andra sceniska elementen till en ny dramatisk syntax. Skyltar, banderoller och projicerade texter blåstes upp för att kommentera det sceniska förloppet. Fotografier och bilddokument, liksom kompletta filmsekvenser projicerades på skärmar och vävar för 
att ge en bakgrund till det gestaltade förloppet eller för att synliggöra alternativa förlopp i egen rätt. Högtalare förmedlade kungörelser eller tal som belyste intrigen från nya vinklar. Och allt detta ägde rum på en ny, öppen och flexibel scen. Piscator avlägsnade inte bara ridåväggen som skilde åskådarnas stolsrader från scenen, utan monterade också ner teaterrummets övriga tre väggar, vilket gjorde det möjligt för honom att utvidga scenen såväl horisontellt som vertikalt med hjälp av ett komplicerat maskineri av hissar, schakt, rullband, vändskivor och scenkonstruktioner med rörliga nivåer och plattformar som kunde tänjas i olika dimensioner för att framsuggerera en bild av samhällets hierarkiska indelningar och rumsliga barriärer.

Detta var vad dåtidens teaterkritiker och publik menade när de talade om Piscator-scenen, eller "Piscator-Bühne", som var ett av Weimarkulturens underverk. Bernhard Diebolds recension av Piscators uppsättning av Walter Mehrings Der Kaufmann von Berlin (Köpmannen från Berlin) år 1929 ger en formidabel uppfattning om den sammankoppling av det teknologiska med det kollektiva som gjorde Piscators produktioner till hänförande multimediala upplevelser:

"Hela serier av tidningsrubriker kastas fram av filmprojektorn mot den välbekanta gasväven ... de historiska ögonblicken ... de obegripliga summorna, riksmark som räknas upp till miljarder flimrar som en snöstorm över den "fjärde väggen" ... Rathenau, Erzberger tonar fram som spöken ur tomrummet ... det antika dramats kör där massmänniskan tog till orda får på så vis nytt liv, fotografiskt, vetenskapligt och objektivt, genom denna spökskärm bestående av luft och tidningsurklipp ... Aldrig förut har själva "gatan” placerats på scen på det sätt som sker här. Den moderna massteatern måste ju, för guds skull, utspela sig på gatan. Vi tar stadsbussen genom filmens raviner av hyreshus ... Ett par löpande band sträcker sig över vridscenen som roterar runt sin egen axel åt ett annat håll. På denna rullar gatorna fram i rasande tempo med tusen steg framåt och tusen bakåt åt höger och vänster. Rummet har en egen roll: gatorna är trafikens rum [... ]” (citerad i Innes 72-73)

Hanns Eisler skrev musiken till Der Kaufmann von Berlin. Lázslo Moholy-Nagy tog fram scenografin. Hans scenskisser förmedlar än i dag en föreställning om komplexiteten hos den sociala och politiska fantasikraft som låg bakom Piscators uppsättningar. I Moholy-Nagys enorma fotoplastiska montage tycks olika kollektiv komma ur intet för att sedan närma sig betraktarens fokus och den historiska scenens mittpunkt. Moholy-Nagy gjorde också omslaget till Piscators bok Das Politische Theater, utgiven år 1929 och tillägnad ”Berlins proletariat”. Omslagsbilden består av ett fotomontage mot röd bakgrund (billede I). 


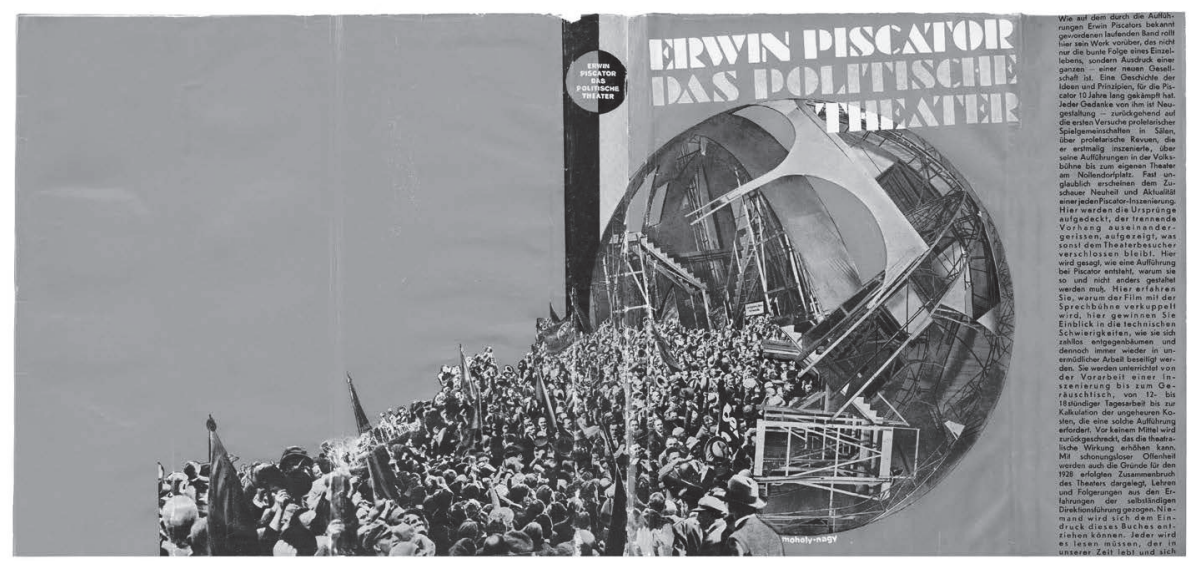

Billede I. László Moholy-Nagy, omslag till Erwin Piscators Das politische Theater, 1929. Foto: David Torell.

Området i nedre vänstra delen av bildfältet täcks av ett urklipp som visar en arbetardemonstration med oräkneliga huvuden och kroppar blandade med röda banderoller och flaggor. Till höger ser vi en rund byggnadsstruktur som tycks bestå av idel trappor, ställningar, valv och balkar, vilket alltsammans ger intryck av en väldig maskinkonstruktion.

Som förlaga använde Moholy-Nagy foton av Piscators så kallade Globus-scen vid Nollendorfplatz i Berlin. På bilden erinrar byggnaden om en sfär eller glob, och massorna som kommer från vänsterkanten tycks vara på väg in i den. Några har redan tagit plats i det sfäriska rummet. Piscator betonade ständigt vikten av att avlägsna alla hinder mellan publiken och teatern. På bokomslagets bild monterade Moholy-Nagy in det avbildade kollektivet ovanpå trapporna och ställningarna i teaterns inre, som för att visa att de på en och samma gång utgjorde en publik på väg in i den runda arenan och samtidigt var de arbetare som kunde hantera dess komplicerade maskineri. Omslaget ger en kongenial framställning av Piscators föreställning om teatern som en plats där tekniken sammansmälter med massorna och bildar ett nytt utopiskt konstbegrepp, där den estetiska formen är omöjlig att skilja från folkets vilja att representera sig självt med det moderna samhällets medel.

\section{När kollektivet tänker}

Piscators medarbetare Eric Mühsam, veteran från den röda rådsrepubliken i München, utarbetade riktlinjerna för arbetet i Piscators teater. På alla teaterns nivåer och inom alla dess verksamhetsgrenar förordade Mühsam det kollektiva samarbetet. Teaterpersonalen skulle forma vad han kallade ett "dramaturgiskt kollektiv", som genomsyrades av principer om jämlikhet, gemensamt ansvarsta- 
gande och kamratskap (Mühsam I42). Som redan nämnts använde man en skådespelarteknik som väckte tanken på kollektiva krafter och konflikter snarare än individuella och existentiella situationer. Viktigast av allt var att teatern försökte väcka publikens delaktighet, förvandla den från en förmodat passiv och opartisk samling till ett aktivt och produktivt kollektiv. Målet var "ett partnerskap där publiken hade en lika viktig roll att spela som scenframställningen" (citerad i Innes I43). Piscators egen dokumentation visar hur han tänkte sig att målet kunde nås, och vilket slags teaterhändelse han hade i tankarna. Han återger till exempel den framgångsrika premiären på Trotz Alledem! (Trots allt!) i juli 1925, en historisk revy baserade på historiska händelser från Första världskriget till Tyska revolutionen, vilken bestod av 23 episoder åtskilda av kortfilmer. Teaterproduktionen rymde även dokumentärfotografi, scenografiska element gjorda av John Heartfield, en arenascen kring vilken publik grupperade sig, ett tjugo meter långt slagskepp som symboliserade den brittiska imperialismen, samt iscensättningar av politiska tal av Karl Liebknecht och Rosa Luxemburg. "Generalrepetitionen var rent kaotisk. Två hundra personer sprang omkring och skrek åt varandra", skriver Piscator, och han fortsätter sedan med en skildring av premiärkvällen. Varje sittplats var upptagen, trapporna, gångarna och dörröppningarna var fullproppade med åskådare:

”De närvarande massorna var redan från början fyllda av upphetsad spänning över att vara med och titta, och ute i publiken kunde man känna en osannolik, generös mottaglighet av det slag man bara märker av hos proletariatet. Men denna mottaglighet förändrades snabbt till aktivt deltagande: massorna övertog regin. Människorna som fyllde byggnaden hade ju till största delen själva varit aktiva under perioden, och det som vi visade dem var i verklig mening deras eget öde; deras egen tragedi iscensattes inför deras egna ögon. Teatern hade blivit verklighet, och snart handlade det inte om en scen som mötte en publik, utan om en enda väldig församling, ett enda stort slagfält, en enda massiv demonstration. Det var denna enhet som denna kväll gav bevis på att politisk teater kan vara effektiv agitation.” (Piscator, Politische Theater 69-70)

Snarlika intryck finns dokumenterade från andra uppsättningar. I Piscators drama om kvinnans reproduktiva rättigheter från I929, §2I8: Framen in Not, (§2I8: Nödställda kvinnor), skrivet av Carl Credé, och en av Piscator-kollektivets mest framgångsrika uppsättningar, uppmuntrades publiken att blanda sig i handlingen med kommentarer, tillrop och tal. I slutet av pjäsen anställdes en omröstning om kriminallagens paragraf 2I8 (som olagligförklarade abort och angav ett straff på fem års fängelse för den gravida kvinnan och den som hjälpte henne i fosterfördrivningen), vilket vanligen ledde till publikens enhälliga förkastande av lagen. På så vis kom pjäsen att övergå i ett offentligt möte och en tillfälligt uppsatt tribunal

I Föreställningen hade premiär på Grosses Schauspielhaus, en av Berlins största teatrar, den I2 juli I925, vilket också var öppningsdagen för det tyska kommunistpartiets (KPD) kongress. 
där folkviljan kom till uttryck. För att uttrycka det enklare, teatern förvandlade sig till demokratiskt forum. (Blätter 8)

Enligt Piscator låg den politiska teaterns hemlighet alltså inte i skapandet av en ny skådespelarteknik eller i utvecklandet av nya dramatiska manuskript. I detta avseende intog han en motsatt inställning till Brecht, som i sin estetik betonade just skådespelartekniken och teaterberättelsen. Piscator menade snarare att den politiska teatern måste grundas på teaterns erövring och användning av den nya teknologin, i synnerhet mediatekniken. Utgångspunkten var ett nytt slags scen, en ny teatermiljö och scenografi, som i sin tur automatiskt skulle frambringa nya skådespelartekniker, en ny dramatik, samt ett nytt sorts engagemang hos publiken. Piscator förklarade: "Och på samma sätt som allmänheten har anpassat sig till den nya sortens boende, därför att det är mer adekvat, rymligare, renare, mer ekonomiskt, och därför även estetiskt sett vackrare, på samma sätt kommer den också att anpassa sig till modern teater, till en ny teaterarkitektur, ett nytt teaterrum, en ny scen, och till nya sceniska specialeffekter: vridbara golv, löpande band, automatiserade hissar, mekaniska bryggor, funktionella scengolv, en underifrån kommande belysning, inslag av film och bildprojektioner, samt till upplösningen av gränsen mellan åskådare och scen" (Piscator, "Technik" II2-II3).

Enligt detta teknikoptimistiska argument skulle tekniken tillåta teatern att upphäva sina tidigare begränsningar och framkalla ett slags massdeltagande som i sin tur skulle demokratisera teatern. När den osynliga väggen mellan scen och salong väl var nedriven kunde teknologin även användas till att förflytta publiken till ett simulerat historiskt rum, en modellverklighet där världshistoriens krafter gjordes närvarande med hjälp av medierade ljud, tecken, signaler och bilder. Massmedia som fotografi, film och tidningstypografi tillhandahöll såväl modeller som material.

\section{Samarbetet med Walter Gropius}

Det säger sig självt att befintliga teaterbyggnader knappast lämpade sig för att förverkliga Piscators ambitioner. Han efterlyste en teater med plats för tre fyra tusen åskådare, och scentekniken skulle vara av senaste märke: "Jag föreställer mig något i stil med en teatermaskin, lika teknisk till sin beskaffenhet som en skrivmaskin, en apparat som är utrustad med de mest moderna belysningssystemen, med hissar och vridskivor i horisontella och vertikala dimensioner, med en mångfald av filmprojektorer, synkroniserade högtalarsystem, etc." (Piscator, Politische Theater I22-I23) I sitt försök att konkretisera dessa planer uppdrog Piscator åt Walter Gropius, ledare för Bauhaus-skolan i Dessau, att projektera en teaterbyggnad som svarade mot hans behov (billede 2). 


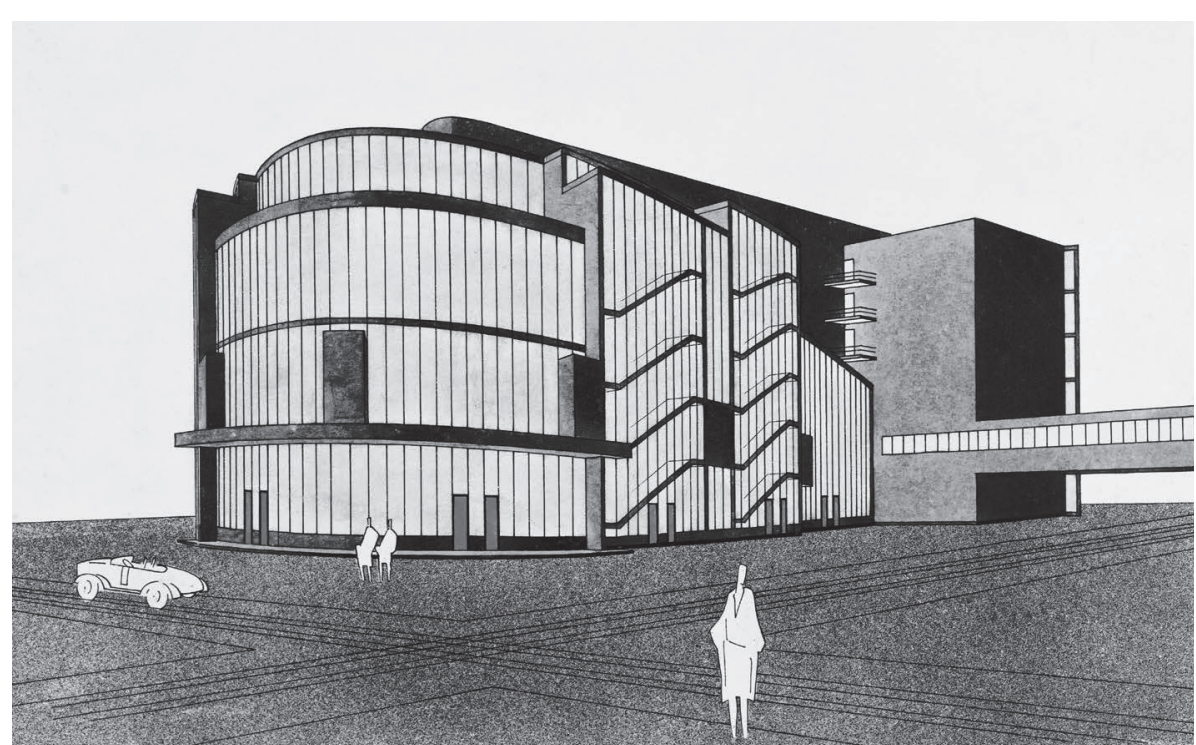

Billede 2. Walter Gropius, skiss till Erwin Piscators Totalteater. Panorama med byggnadens exterior. Harvard Art Museums/Busch-Reisinger Museum, Gift of Walter Gropius,

BRGA.24.100. Photo: Imaging Department () President and Fellows of Harvard College.

Planen gick under namnet Totalteatern (Das Totaltheater). ${ }^{2}$ Totalteatern syftade både på ett dramaturgiskt begrepp och på ett arkitektoniskt, och bakom begreppet gnistrar utopin om teaterkonstens fullkomliga frihet och föränderlighet. Gropius tänkte ut ett maskineri som gjorde det möjligt att flytta scenen genom åskådarrummet så att det än begränsade publikrummet, än placerades i dess mitt. Teaterns inre kunde därför växla mellan tittskåpsteatern, amfiteatern och arenateatern beroende på vilket slags produktion man önskade sig (Gropius). Allt från Aiskylos, Shakespeare och Molière till Tjechov, Ibsen, Toller, Brecht och det moderna dokumentärdramat skulle här kunna uppföras med samma ledighet, och därutöver naturligtvis opera, cirkusföreställningar, idrottstävlingar och politiska massmöten.

Om agitprop hade inneburit teaterns avsked av scenen och förflyttning ut i samhället så försökte Totalteatern placera samhället som sådant på scenen. Enligt teaterhistorikern Stefan Woll försökte Piscators och Gropius' Totalteater för första gången på allvar infria föreställningen om teatern som samhällets konstituerande

2 Piscators och Gropius' föreställning om Totalteatern bör särskiljas från vad som under samma tid i Sovjetunionen ofta kallades "total teater", som ofta hänvisade till utomhusevenemang och festivaler där tusentals människor deltog $\mathrm{i}$ åminnelsen och återuppförandet av den ryska revolutionens stora händelser (Se Rolf). Den ska också särskiljas från László Moholy-Nagys idéer om vad han kallade "totalitetens teater" (Theater der Totalität) - i sekundärlitteraturen också nämnd som "the Bauhaus Totaltheater" -som utgjordes av en rent mekanisk syntes där en apparatur bestående av geometriska figurer, spriraler, sfärer, färgytor och mekaniska kroppar placerades på scen och sattes i rörelse av ett motordrivet maskineri (Smith; för en jämförande diskussion, se Woll I2O-I22). 
makt och som folkets kulturella och politiska medvetande (Woll Io9). Enligt Piscators egen definition var Totalteatern "en byggnad som är 'totalt' performativ, $\mathrm{i}$ vilken åskådaren som spatialt centrum är omgiven av en 'total' scen och är 'totalt' konfronterad med denna. De historiska händelsernas synkroni, den sociala och politiska aktionens och reaktionens samtidighet, kan i ett och samma nu representeras på denna scen, på denna sceniska totalitet." (Piscator, "Totaltheater" I36)

I dag framstår Gropius' och Piscators planer som själva summan av alla de utopiska tendenser och projekt som karakteriserade försöken att förnya teaterinstitutionen efter första världskriget. Än viktigare är att projektet i sig förkroppsligar en av Weimarkulturens intressantaste idéer om kollektiv själv-representation. Piscators teater skulle uttryckligen byggas som ett massornas hus, och tekniken i detta hus skulle ge dem en sann bild av deras historiska och samhälleliga situation. Genom sitt överskridande och sin upplösning av gränsen mellan publik och dramatik uppmuntrar Piscator till ett tänkande teatern omsluter samhället i dess helhet.

Gropius' och Piscators projekt är på så vis ett exempel på vad Walter Benjamin menade när han skrev att "massorna är den matris" varigenom konstbegreppet förändras i grunden (Benjamin, "Kunstwerk" 464). Totalteatern var tänkt som en ny konstform som var baserad på kollektivet snarare än individen. Genom att integrera den nya mediatekniken skulle teatern bli en plats där massorna kunde absorbera konstverket och införliva det med sitt politiska väsen. Stefan Woll betonar processens kollektiva karaktär, i vilken det dramatiska verket sprids ut i samma kollektiv som antas förkroppsliga det. "Genom att utveckla sig till ett massfenomen skulle Totalteaterns teaterhändelse förvandlas till masshändelse, och på så vis bidra till att skapa föreställningen om Totalteatern som genuin massteater." (Woll I36)

Vi måste fråga oss huruvida Piscators projekt verkligen skilde sig på något avgörande vis från den fascistiska estetik genom vilken Nazismen kort senare bjöd in det tyska folket att hänföras av sin egen enhet i festivaler och på massarenor (Se Karlsson \& Ruth; Schnapp). Vad skiljer Gropius och Piscators Totalteater från en totalitär teater, där regissörsgeniet drar i teatermaskinens spakar för att framkalla de förväntade reaktionerna och känslorna hos de kollektiv som han dirigerar och kontrollerar?

Skillnaden respektive likheten mellan Piscators estetik och den fascistiska statens kollektivexperiment tycks sammanfalla med de skillnader och likheter som vi kan se mellan kommunismen och Nationalsocialismen som helhet. Men i kontrast till de manipulerade skådespel som Kracauer kallade "massans ornament" och även till Nazismen iscensatta massfester så strävade Piscators massteater aldrig efter att harmonisera och släta ut kollektivets inre spänningar och olikheter; Piscators mål var inte att skapa en folkets enhet där alla stämdes samman till en organisk eller exalterad helhet. Idealet förblev snarare den bråkiga och diskuterande församlingen, animerad av olikheter, vilket inte låg så långt borta från arbetarrådens verklighet under den tyska revolutionen. 
Fast man ska inte heller glömma att Piscators teater i hög grad var kalibrerad för att tilltala Berlins hyperkritiska och intellektuellt sofistikerade teaterpublik, som alltid önskade sig scenkonstens nyaste underverk. Därför åtnjöt Piscator långt mer uppmärksamhet från huvudstadens borgerliga intelligentsia än från Berlins arbetarklass i Wedding och Neukölln. Ingenstans i Piscators dramatiska verk möter vi heller den sammansmältning mellan ledaren och massan som var ett av den fascistiska teaterestetikens typiska drag. Om den fascistiska estetiken lärde massorna att njuta av och se meningen i sin underkastelse under ledaren, så att de förvandlades till vad Klaus Theweleit kallar ett "block" eller en "molär" massa, så syftade Piscators estetik alltid på att lära den proletära allmänheten att inte lita på sina omedelbara intryck utan i stället utsätta alla förnimmelser och diskurser för kritisk analys; hans massa förblev på så sätt ett mångfaldigt, heterogent och "molekylärt" kollektivsubjekt (Theweleit 2: 89-94).

Men först som sist är det den utopiska dimensionen i Piscators projekt som fängslar eftervärlden, samt att utopin innebar en fullständig sammanflätning av det estetiska och det politiska. Projektet utforskade teaterns möjlighet att låta folk representera sig själva och att låta dem själva verifiera huruvida teaterrepresentationen var en sann framställning av deras historiska situation. Teatern var för Piscator ett rum och en byggnad i vilket folket, socialt uppdelat och bestående av otaliga isolerade och alienerade individer, bjöds in att betrakta och behandla varandra som likställda medmänniskor. På så sätt skulle teatern erbjuda dem en erfarenhet av gemenskap som det kapitalistiska samhället förnekade dem, och denna erfarenhet skulle hjälpa dem att inte bara överleva detta förnekande utan också göra motstånd mot det. Fundamentet i denna estetik är med andra ord ett begrepp om massorna eller proletariatet som representativa inte bara för folket i dess snäva nationalistiska mening utan för mänskligheten som sådan, bortom klasskillnader och sociala gränser.

I den socialistiska teologi som Paul Tillich utvecklade under samma år på I920-talet framstod massorna som en mänsklig gemenskap i vardande som överskred "motsättningen mellan massa och individ" (Tillich 25-55). På denna utopiska nivå ser vi att den publik eller det kollektivsubjekt som Gropius och Piscator önskade frambringa med sin teater står i samklang med den universella agens som Tillich tillskrev Tysklands arbetande klasser i gemen.

\section{Samhällets öga}

Betraktar man Gropius' utkast till Totalteatern märker man att byggnaden sedd ovanifrån och i tvärsnitt liknar ett öga (billede 3). 


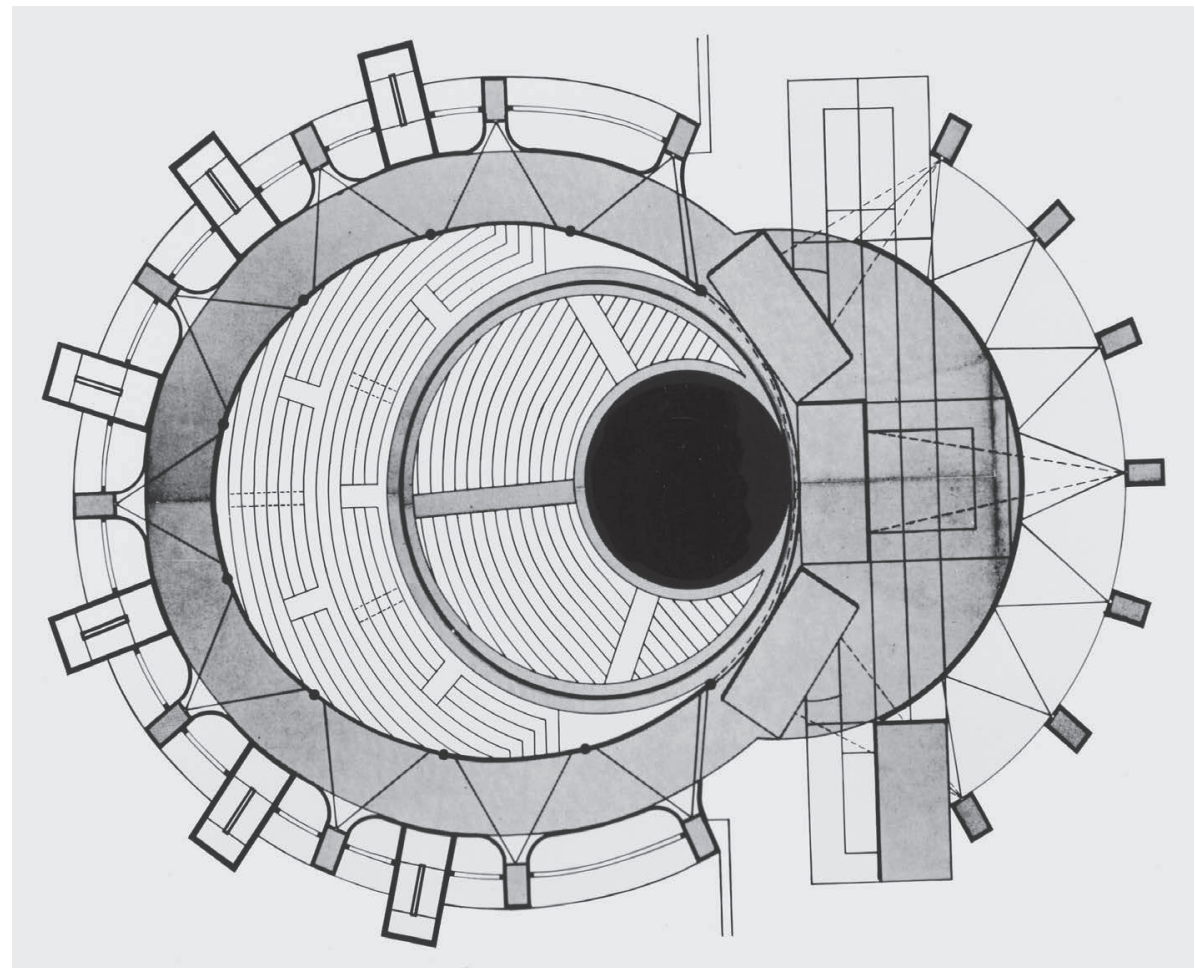

Billede 3. Walter Gropius, Erwin Piscators Totalteater, 1927. Golvplan. Harvard Art Museums/ Busch-Reisinger Museum, Gift of Walter Gropius, BRGA.24.72. Photo: Imaging Department () President and Fellows of Harvard College.

Stolsraderna som är placerade i byggnadens ovala rum täcker den yta som svarar mot ögats iris. Linjerna som märker ut film- och ljudanläggningarnas projektionsriktningar strålar från periferin mot mittpunkten genom ögats glaskropp. Strax utanför ovalens centrum finns en cirkulär form som symboliserar scenen och förscenen, vilka förstås alltid ligger i dramats fokus. På Gropius’ teckning liknar scenen ögats pupill, ljusöppningen genom vilken världen släpps in och varseblivs. Liksom ögat är en elastisk kropp, vilket gör att pupillen kan röra sig vertikalt och horisontellt, så skulle Totalteaterns scen ha maximal rörlighet i alla dimensioner så att den kunde sänka, höja och vrida sig, och dessutom flytta sig till utkanten av publikrummet eller in i dess mitt. Teaterrummet arkitektur skulle med andra ord anpassa sina kommunicerande organ till publikens emotionella läge och teaterverkets form och innehåll.

Så sett framstår Totalteatern som ett enda stort öga genom vilket publiken kunde förnimma samhället och världen. Kanske var det just så Piscator föreställde sig den politiska teaterns målsättning: att hjälpa publiken skaffa sig ett extra öga genom vilket kollektivet skulle kunna se vad ingen av dess medlemmar kunde uppfatta var och en för sig: själva relationerna som band samman och bestämde 
mönstret för den ekonomi och politik som dirigerade deras liv. Totalteatern blir på så vis ett socialt öga, med förmåga till ett estetiskt och historiskt seende som är unik för kollektivet.

Mellankrigstidens sociologer och socialpsykologer såg ofta massorna som blinda (Jonsson). Piscator ställde sig på de blinda dårarnas sida och visade att de tillsammans ägde ett eget, överlägset synsinne. Så kunde samhället och folket skymta en glimt av sin egen livsform: "kollektivets ogripbara former", som Walter Benjamin kallade den i en av sina essäer (Benjamin, "Neues" I5I-I52). Han tänkte på den nya estetikens förmåga att synliggöra samhällets utopiska väsen.

\section{LITTERATURLISTA}

Balázs, Béla. “Theater auf der Strabe.” Deutsches Arbeitertheater I9I8-I933. 2: 454-456.

Balázs, Béla. "Theater des Volkes”. Die neue Schaubühne I (I9I9): 201.

Benjamin, Walter. Gesammelte Schriften. 7 vol. i I5 band. Red. Rolf Tiedemann och Hermann

Schweppenhäuser. Frankfurt am Main: Suhrkamp, I972-I999.

Benjamin, Walter. "Das Kunstwerk im Zeitalter seiner technischen Reproduzierbarkeit”. Gesammelte Schriften. I, 2: 43I-47I.

Benjamin, Walter. "Neues von Blumen”. Gesammelte Schriften. III, I: I5I-I52.

Blätter der Piscatorbühne-Kollektiv. Nummer 8, Frauen in Not: Weg mit dem §2I8. April I930.

Brecht, Bertolt. Kuble Wampe: Protokoll des Films und Materialen. Red. Wolfgang Gersch och Werner

Hecht. Frankfurt am Main: Suhrkamp, 1969.

Bürger, Peter. Theory of the Avant-Garde. Övers. Michael Shaw. Minneapolis: University of Minnesota Press, I984.

Deutsches Arbeitertheater 19I8-1933. 2 vol. Red. Ludwig Hoffmann och Daniel Hoffmann-Ostwald. Berlin: Henschelverlag Kunst und Gesellschaft, 1977.

Diebold, Bernhard. (Review), Frankfurter Zeitung, II September I929. Citerad i Innes, Erwin Piscator's

Political Theater, $72 \mathrm{f}$.

Dudow, Slatan et al. Kuble Wampe oder Wem gehört die Welt? DVD. Frankfurt am Main: Filmedition Suhrkamp, 2008.

Gropius, Walter. "vom modernen theaterbau, unter berücksichtigung des piscator-theater-neubaues in berlin". Berliner Tageblatt. 2 Nov. 1927.

Hoffmann, Ludwig. "Einleitung". Deutsches Arbeitertheater I9I8-I933. I: 38-46.

Innes, Christopher D. Erwin Piscator's Political Theatre: the development of modern German drama.

Cambridge: Cambridge University Press, I972.

Jonsson, Stefan. Crowds and Democracy: The Idea and Image of the Masses from Revolution to Fascism. New York: Columbia University Press, forthcoming in 2013.

Karlsson, Ingemar och Arne Ruth. Sambället som teater: estetik och politik i Tredje riket. Stockholm: Liber förlag, I984.

Kleberg, Lars. Theater as Action: Soviet Russian Avant-Garde Aesthetics. New York: NYU Press, I993. 
Mühsam, Eric. "Richtlinien für das dramaturgische Kollektiv der Piscator-Bühne”. I Piscator, Das politische Theater, I42-I43.

Pieck, Arthur. "Polizeiknüppel über Deutschland.” Deutsches Arbeitertheater 19I8-1933. 2: 27I-276.

Piscator, Erwin. "Bühne der Gegenwart und Zukunft”. I Piscator, Theater der Auseinandersetzung. 2O-2I.

Piscator, Erwin. “Grundzätzliches,” I programbladet Gastspiel der Piscatorbühne, Carl Credé, § 2I8:

Gequälte Menschen, 7, Berlin Akademie der Künste, Piscator-Center, signum 69.

Piscator, Erwin. Das politische Theater. Berlin: Adalbert Schultz Verlag, I929.

Piscator, Erwin. Theater der Auseinandersetzung: Ausgewählte Schriften und Reden. Frankfurt am Main: Suhrkamp, I977.

Piscator, Erwin. “'Technik': Anklage und Freispruch”. I Piscator, Theater der Auseinandersetzung, 76.

Piscator, Erwin. “Technik - eine künstlerische Notwendigkeit des modernen Theaters”. In Piscator,

Theater der Auseinandersetzung, II2-II3.

Piscator, Erwin. "Totaltheater und totales Theater". I Piscator, Theater der Auseinandersetzung, I35-I37.

Piscator, Erwin. "Über Grundlagen und Aufgaben des proletarischen Theaters”. Deutsches

Arbeitertheater 19I8-1933. I:69-70.

Rolf, Malte. Das sowjetische Massenfest. Hamburg: Hamburger Edition, 2006.

Schnapp, Jeffrey. Staging Fascism: I8 BL and the theater of masses for masses. Stanford: Stanford University Press, 1996.

Smith, Matthew W. "Schlemmer, Moholy-Nagy, and the Search for the Absolute Stage”. Theater 32 (2002), no. 3. 87-IOI.

Theweleit, Klaus. Männerphantasien. Vol. 2: Männerkörper: zur psychoanalyse des weißen Terrors. Frankfurt am Main: Roter Stern, I978.

Tillich, Paul. Masse und Geist: Studien zur Philosophie der Masse. Berlin och Frankfurt am Main: Verlag der Arbeitsgemeinschaft, 1922.

Woll, Stefan. Das Totaltheater: Ein Projekt von Walter Gropius und Erwin Piscator. Berlin: Gesellschaft für Theatergeschichte, I984. 